\title{
Gene action and combining ability estimates of newly developed CMS based heterotic rice hybrids (Oryza sativa L.)
}

\author{
R. Madhuri ${ }^{1 *}$ N. Shivakumar ${ }^{2}$, K. G. Bindhu ${ }^{3}$, H. C. Lohithaswa ${ }^{4}$, and R. $\operatorname{Pavan}^{5}$ \\ ${ }^{1}$ Department of Genetics and Plant Breeding, University of Agricultural and Horticultural Sciences, Shivamogga \\ -577 204 (Karnataka), INDIA \\ ${ }^{4 \& 5}$ Department of Genetics and Plant Breeding, College of Agriculture, V. C. Farm, Mandya- 571405 (Karnataka), INDIA \\ ${ }^{2}$ Hybrid Rice Section, Zonal Agricultural Research Station, V. C. Farm, Mandya- 571405 (Karnataka), INDIA \\ ${ }^{3}$ Department of Plant Pathology, University for Agricultural Sciences, Raichur -584 104(Karnataka), INDIA \\ *Correspondence Email: madhu13madhuri@gmail.com
}

Received: December 2, 2016; Revised received: April 5, 2017; Accepted: August 2, 2017

Abstract: An insight knowledge nature and relative magnitude of gene actions involved and combining ability is useful for a breeder to assess nicking ability in self-pollinated crops. In this connection, an attempt was made to estimate the gene action and combining ability of 70 newly developed CMS based heterotic rice hybrids developed from ten newly developed CMS lines and seven testers were evaluated for grain yield and its components at Hybrid rice scheme, ZARS, V. C. Farm, Mandya. Among the lines, CMS 2 had significant gca effects at $1 \%$ level of significance in desired direction for four traits viz., panicle weight, pollen fertility, spikelet fertility and number of spikelets per panicle. Out of seven testers, KMR 3 found to be good general combiner for five traits viz., days to 50 per cent flowering, plant height, number of tillers per plant, number of panicles per plant and grain L/B ratio. Among the 70 hybrids, CMS1 $\times$ KMR3 was good specific combiner for grain yield per plant and grain L/B ratio. It further revealed that SCA variances were higher than the GCA variances for all the characters which indicated preponderance of non-additive gene action. Hence, CMS 2 and KMR 3 are identified as promising lines which can be used in further breeding programme.

Keywords: CMS lines, Combining ability, Gene action, GCA, SCA

\section{INTRODUCTION}

Rice is an important cereal crop and staple food crop of India which occupies an area of 43.97 million ha which is the largest in the world, with an annual production of around 106.3 million tonnes which is the second largest in the world after China. To meet the demands of increasing population and to maintain self-sufficiency, the present production levels need to be increased up to 120 million tons by 2020 . The production of rice needs to be increased by almost 2 million tons every year. In order to keep pace with the growing population, the production and productivity of rice needs to be enhanced. It has been proved that use of Cytoplasmic Male Sterility (CMS) in developing rice hybrids increases grain yield by more than $20 \%$ relative to improved inbred rice varieties (Yuan and Virmani, 1994) and also an insight knowledge of nature and relative magnitude of gene actions involved and combining ability of the parents used in hybridization in the genetic improvement of the crop is needed for a breeder to assess nicking ability in self pollinated crops. According to Arunachalam (1976), the combining ability is a better biometrical tool to circumvent the plant breeding program. Among large array of biometrical procedures for relative estimation of genetic components, line $\mathrm{x}$ tester by Kempthorne (1957) is an efficient procedures as it allows for inclusion of a large number of lines and provides reliable estimates of genetic components, estimates of combining ability and gene action governing a complextrait. Therefore, the present investigation was carried out with a view to understand the nature of gene action and combining ability for yield and its attributesin newly developed CMS based heterotic rice hybrids through line $\times$ tester analysis.

\section{MATERIALS AND METHODS}

The experiment comprised of ten newly developed CMS lines (Table 1) and seven testers (Table 2) are crossed in line $\times$ tester mating design as suggested by Kempthorne (1957). Clipping and dusting method of crossing was followed to produce $70 \mathrm{~F}_{1}$ 's at Hybrid rice scheme, ZARS, V. C. Farm, Mandya during summer 2014. The resulting $70 \mathrm{~F}_{1}$ 's along with their parental lines 
and three standard checks viz., KRH-2, KRH-4 and GK5003 were evaluated at Hybrid rice scheme, ZARS, V. C. Farm, Mandya during Kharif 2014. The experimental site is located at latitude of $12^{\circ} 30^{\prime} \mathrm{N}$, longitude of $76^{\circ} 50^{\prime} \mathrm{E}$ and altitude of 694.65 meters above mean sea level (MSL) with red sandy loam soil type. The experiment was raised by transplanting seedling with a spacing of $20 \mathrm{~cm} \times 15 \mathrm{~cm}$ in single rows with single seedling per hill in a Randomized Complete Block Design (RCBD) with two replications. All the recommended package of practices was followed timely to ensure good crop establishment. The observation on grain yield and its 12 important component traits were recorded from five competitive plants which were selected randomly. The mean values of these ten plants were used for combining ability analysis (line $\times$ tester) as computed according to the model given by Kempthorne (1957).

\section{RESULTS AND DISCUSSION}

The analysis of variance carried out for 12 quantitative traits studied indicated that highly significant differences at $1 \%$ level of significance existed among the genotypes, thereby justifying the use of experimental material for the study (Table 3). The mean sum of squares due to hy- brids was highly significant at $1 \%$ level of significance, indicating the diverse performance of different cross combinations. The mean sum of squares due to parents versus crosses was highly significant for all traits except for grain L/B ratio, revealing the presence of heterosis due to the significant difference in the mean performance of hybrids and parents. These results were in agreement with earlier reports of Ananda $\mathrm{Ku}-$ mar et al. (2004), Kumar et al. (2008), Abhinav and Motiramani (2006) and Fiaz et al. (2006) in rice. Significant differences were also observed in all traits for both testers (male) and lines (females) justifying there is a scope for selection of parents in the present study.

Combining ability analysis of present study revealed that both GCA and SCA variances among various traits studied were important for the inheritance of traits (Table 4). It further revealed that SCA variances were higher than the GCA variances which indicated preponderance of non-additive gene action for all the characters. These results are in conformity with the findings of Ganesan et al. (1998), Vanaja et al. (2003), Anand Kumar et al. (2004), Sharma and Mani (2008), Utharasu and Anand Kumar, (2013) and Dadilakshmi and Upendra (2014) in rice.

Table 1. List of CMS lines along with parentage and source of cytoplasm.

\begin{tabular}{cclc}
\hline Sl. No & CMS lines & Parentage & Cytoplasmic source in CMS line (A line) \\
\hline 1 & CMS 1 & KCMS 40A & CMS - WA \\
2 & CMS 2 & KCMS 48A & CMS - WA \\
3 & CMS 3 & IR 68888A/Pragathi & CMS - WA \\
4 & CMS 4 & IR 68902A/MSN- 20-12-1-2 & CMS - WA \\
5 & CMS 5 & IR 68896A/MSN 43 & CMS - WA \\
6 & CMS 6 & IR 68888A/IR 20 & CMS - WA \\
7 & CMS 7 & IR 68888A/MSN-20-13-1-1 & CMS - WA \\
8 & CMS 8 & IR 70369A/MSN 96 & CMS - WA \\
9 & CMS 9 & IR 70365A/IR 20 & CMS - WA \\
10 & CMS 10 & IR62829A/IR 30864 & CMS - WA \\
\hline
\end{tabular}

Table 2. List of testers used along with their parentage.

\begin{tabular}{lll}
\hline Sl. No & Testers & Parentage \\
\hline 1 & MSN -36 & Selection from MRP 5180a \\
2 & KMR -3 & Jaya/IR29723-143-3-2-1 \\
3 & MSN -71 & IR 9761/KMR 3R \\
4 & MSN -15-16 & Jyothi/ KMR 3R \\
5 & PBK 093-1-4-2-1 & IR60919/ MSN-36 \\
6 & PBK 095-5-4-5-1 & CRMS 32 B/Thanu \\
7 & PBK 091-3-7-1-1 & MSN- 98/Athira \\
\hline
\end{tabular}


R. Madhuri et al. / J. Appl. \& Nat. Sci. 9 (3): 1557 -1565 (2017)

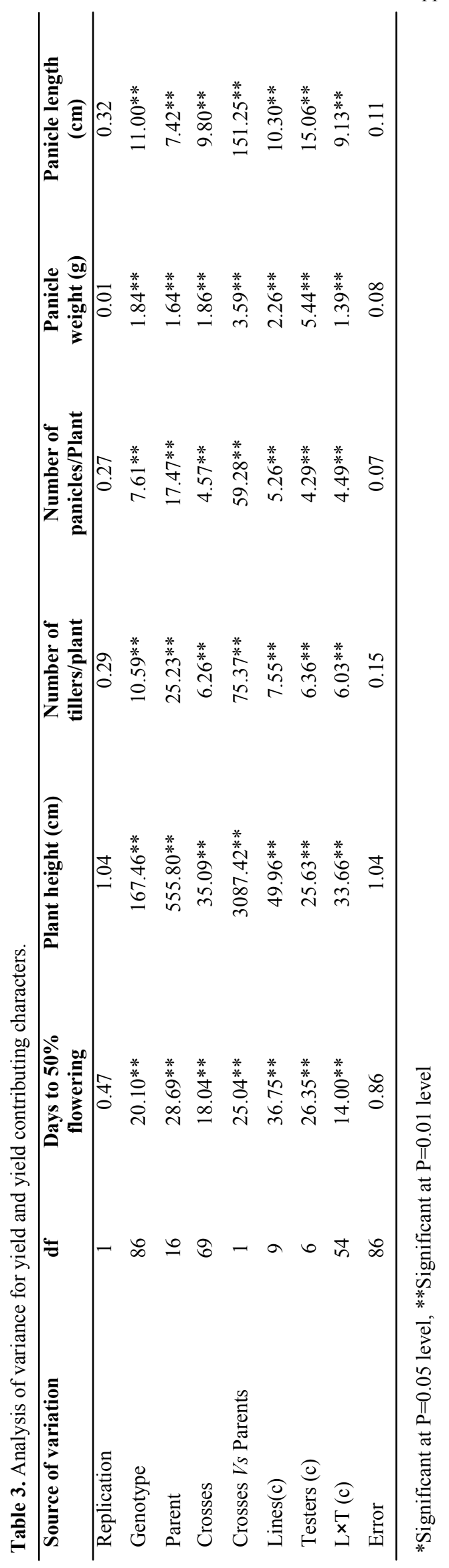

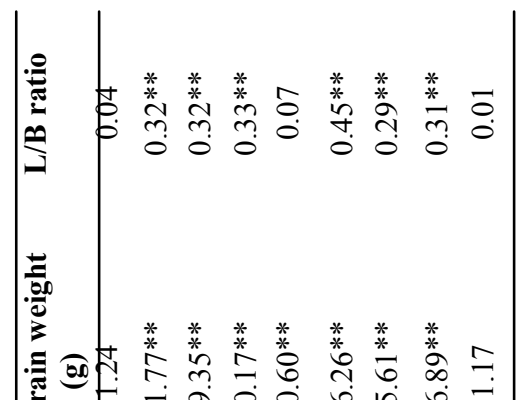

苟

压

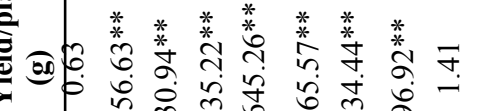

कू

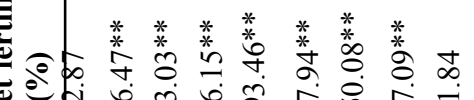

की

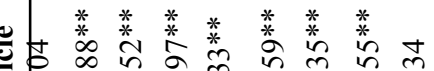

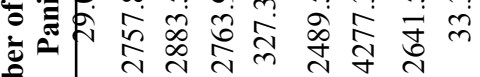

蒙

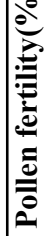

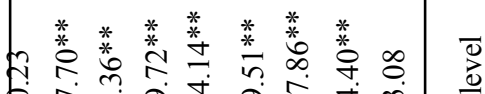

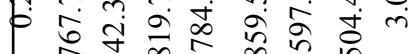

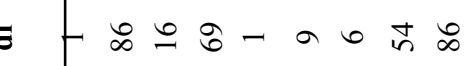

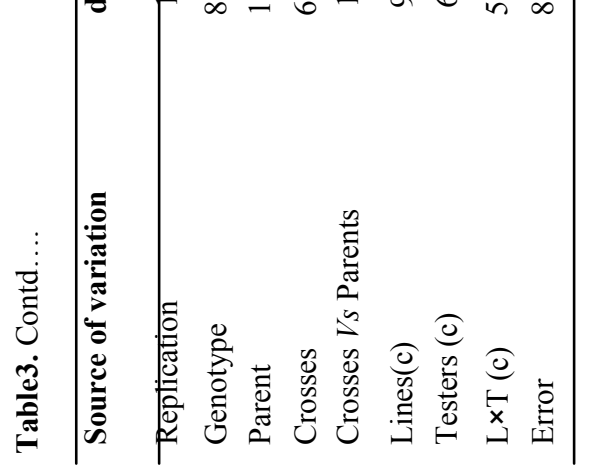

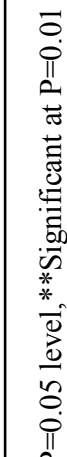


R. Madhuri et al. / J. Appl. \& Nat. Sci. 9 (3): 1557 -1565 (2017)

Table 4. Estimates of variance components for yield and yield contributing characters.

\begin{tabular}{clccc}
\hline Sl. No & \multicolumn{1}{c}{ Characters } & $\boldsymbol{\sigma}^{2} \mathbf{G C A}$ & $\boldsymbol{\sigma}^{2} \mathbf{S C A}$ & $\boldsymbol{\sigma}^{2} \mathbf{G C A} / \boldsymbol{\sigma}^{2} \mathbf{S C A}$ \\
\hline 1 & Days to 50\% flowering & 0.08 & 6.59 & 0.01 \\
2 & Plant height (cm) & 0.03 & 16.34 & 0.002 \\
3 & Number of tillers/plant & 0.00 & 2.94 & 0.001 \\
4 & Number of panicles/plant & 0.00 & 2.20 & 0.0007 \\
5 & Panicle weight(g) & 0.01 & 0.66 & 0.01 \\
6 & Panicle length(cm) & 0.01 & 4.51 & 0.002 \\
7 & Pollen fertility(\%) & 5.90 & 250.86 & 0.02 \\
8 & Number of spikelets/panicle & 2.29 & 1304.54 & 0.0001 \\
9 & Spikelet fertility (\%) & 7.09 & 297.66 & 0.02 \\
10 & Seed yield per plant (g) & 0.72 & 48.18 & 0.01 \\
11 & 1000 grain weight $(\mathrm{g})$ & 0.06 & 7.81 & 0.007 \\
12 & L/B ratio & 0.00 & 0.15 & 0.001 \\
\hline
\end{tabular}

The gca effects calculated for each parent are presented in Table 5. The parents with higher magnitude of gca effects were considered as superior to those with lower magnitude. The overall estimate of $\mathrm{gca}$ effects revealed that among 10 lines, CMS 2 had significant gca effects in desired direction for four traits viz., panicle weight, pollen fertility, spikelet fertility and number of spikelets per panicle. Out of seven testers, KMR 3 found to be good general combiner for five traits viz., days to 50 per cent flowering, plant height, number of tillers per plant, number of panicles per plant and grain L/B ratio. While, PBK 091-3-7-1-1 had high gca effects in desired direction for number of spikelets per panicle, seed yield and 1000 grain weight. Superiority of female and male parents based on gca effects was also reported by Swamy et al. (2003), Abhinav and Motiramani (2006) and Patil et al. (2011) in rice.

Among 70 hybrids, CMS $9 \times$ MSN 71 was found to be a good specific combiner for two traits viz., number of tillers per plant and number of panicles per plant (Table 6). The hybrid, CMS1 $\times$ KMR3 was a good specific combiner for grain yield per plant and grain L/B ratio in desirable direction. For pollen fertility and spikelet fertility, the hybrid CMS2 $\times$ MSN 71 was found superior. Most of the hybrids showed highly significant sca effects for plant height, among these hybrids, CMS4 $\times$ PBK 093-1-4-4-2-1 and CMS5 × PBK 091-3-7-1-1were identified as best specific combiners for plant height. The hybrids CMS3 $\times$ PBK 095-5-4-5-1 and CMS10 × MSN 71 showed highly significant $s c a$ effects and are identified as best specific combiner for panicle weight and panicle length, respectively. In the same line, Swamy et al. (2003), Jagadeesan and Ganesan (2006), Nadali and Babaein (2010), Saidaiah et al. (2010), Tiwary et al. (2011), Patil et al. (2011) and Damodar et al. (2014) identified good specific combiners for different yield attributing traits in rice based on high $s c a$ effects in desirable direction.

\section{Conclusion}

Among lines, CMS 2 had significant gca effects in desired direction for four important yield contributing traits viz., panicle weight, pollen fertility, spikelet fertility and number of spikelets per panicle. Among testers, KMR 3 was found to be a good general combiner for the five important yield contributing traits viz., days to 50 per cent flowering, plant height, number of tillers per plant, number of panicles per plant and grain L/B ratio while, PBK 091-3-7-1-1 showed high gca effects in desired direction for number of spikelets per panicle, seed yield and 1000 grain weight. Among crosses, CMS $1 \times$ KMR3 was identified as good specific combiner for seed yield per plant which need to be tested and released for commercial cultivation. Selection of parents with good combining ability for selective traits that could complement each other favourably in the hybrids would be a desirable approach to breed better hybrid combinations. Thus, these testers and cross combinations could be used for exploitation of heterosis in further hybrid breeding program. 


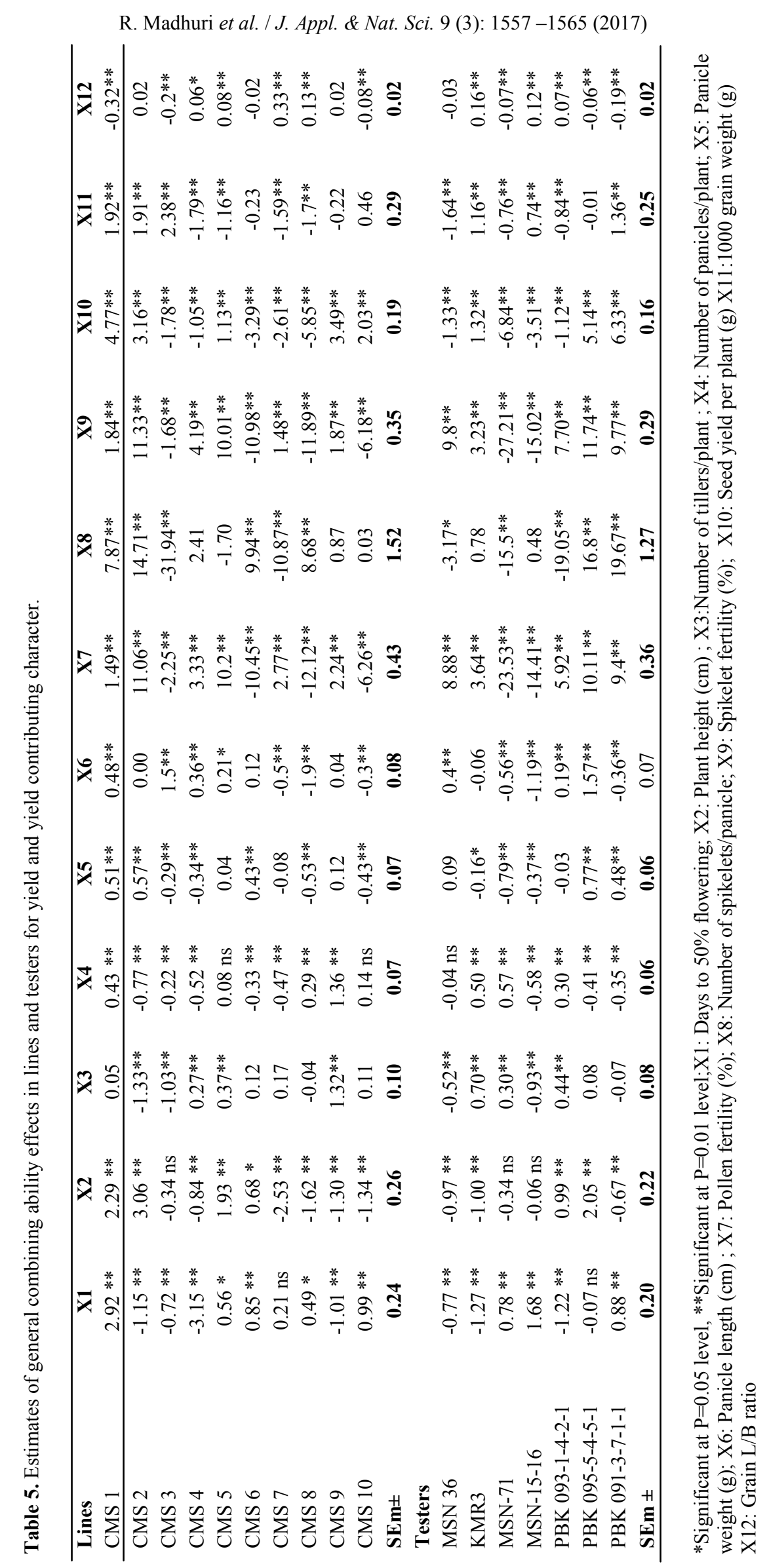




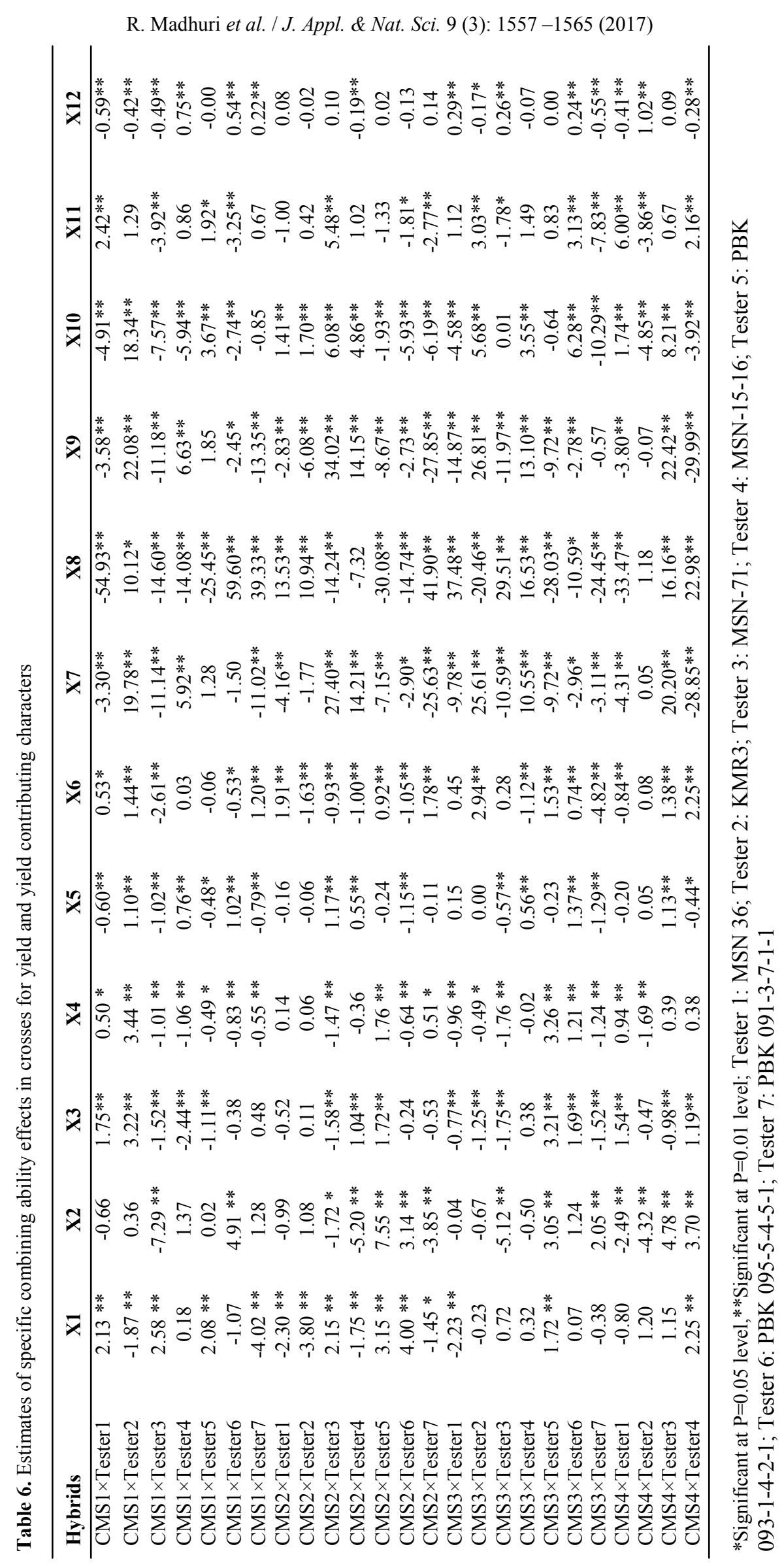

1562 
R. Madhuri et al. / J. Appl. \& Nat. Sci. 9 (3): 1557 -1565 (2017)

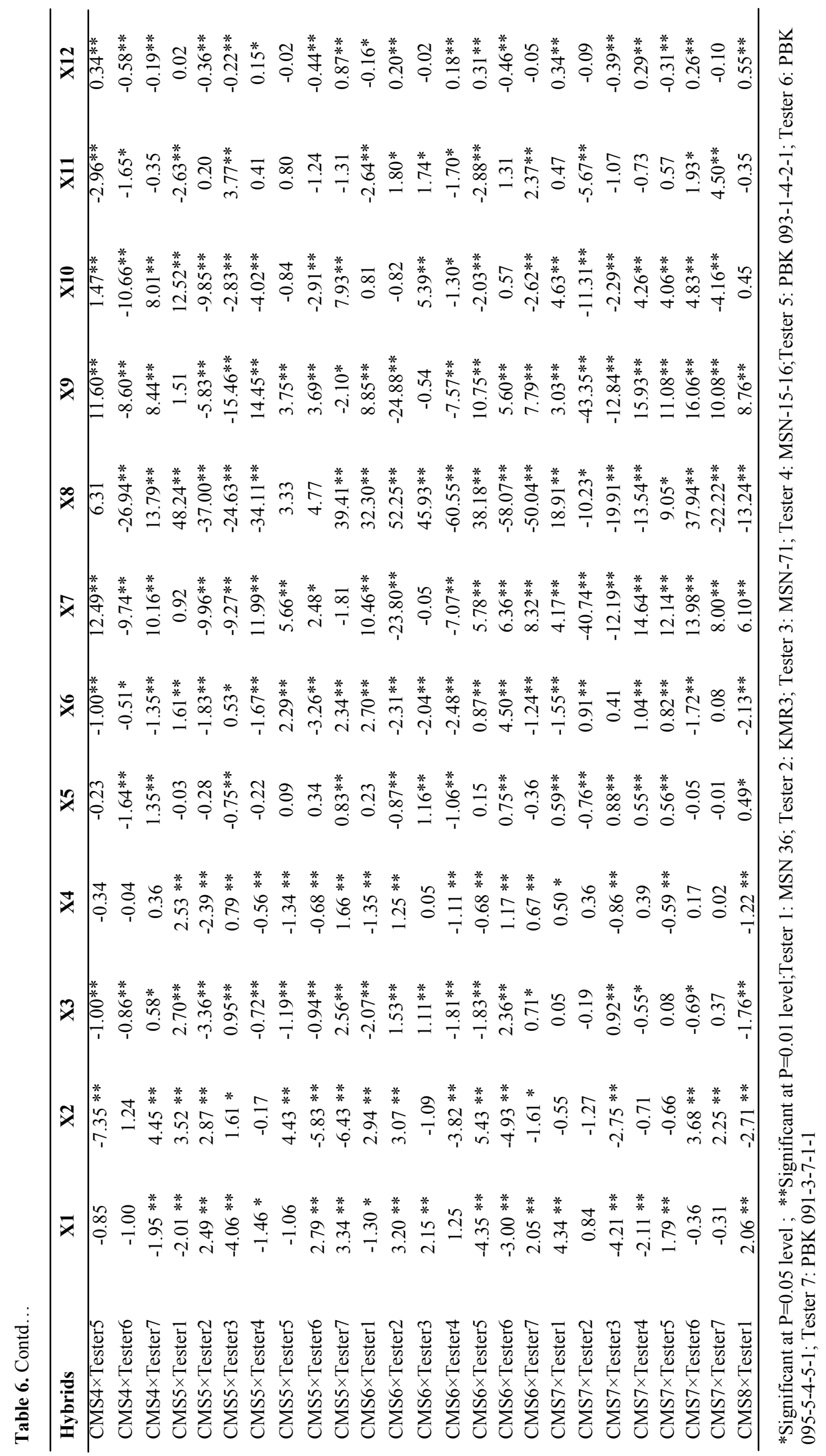


R. Madhuri et al. / J. Appl. \& Nat. Sci. 9 (3): 1557 -1565 (2017)

|

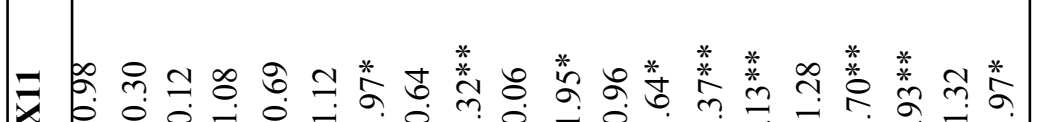

x

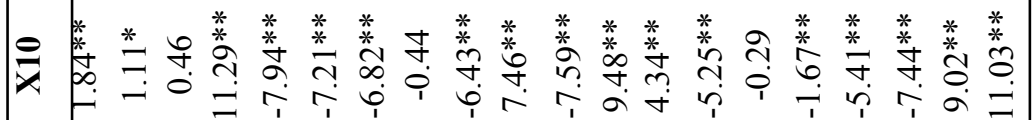

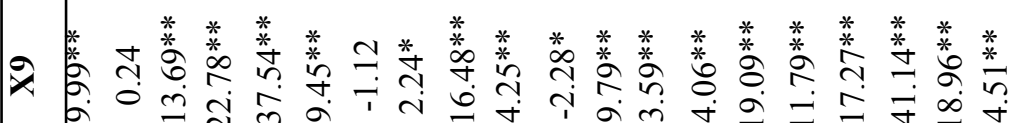

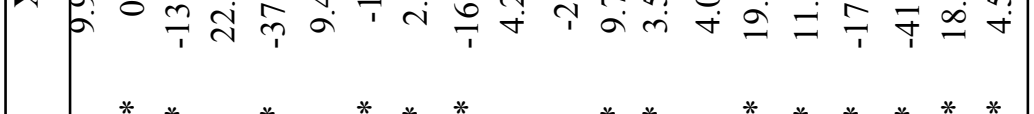

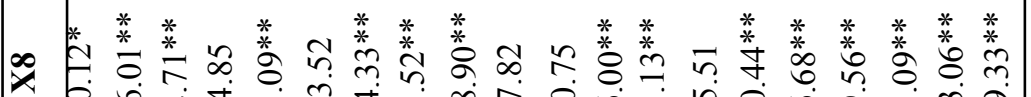

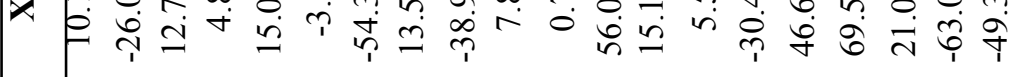

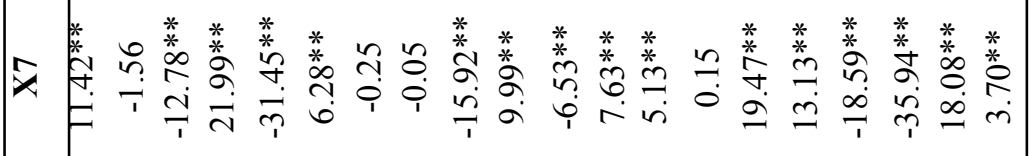

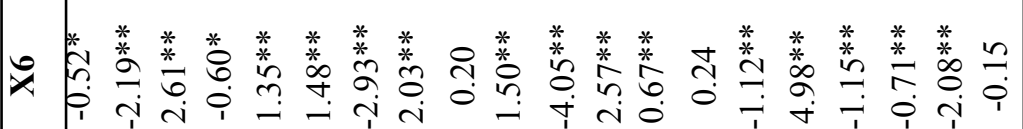

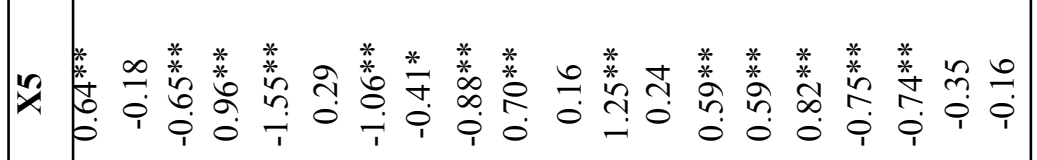

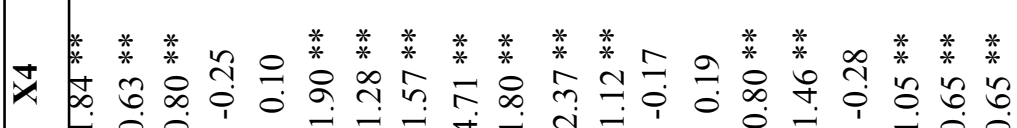

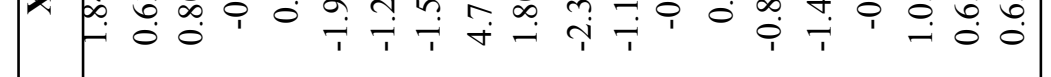

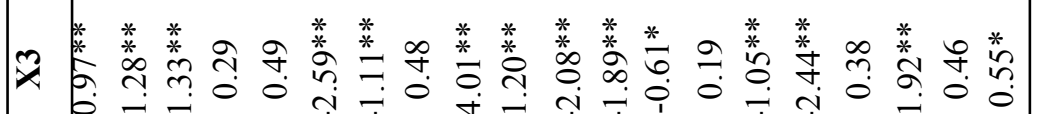

P

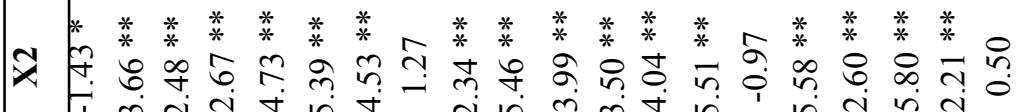

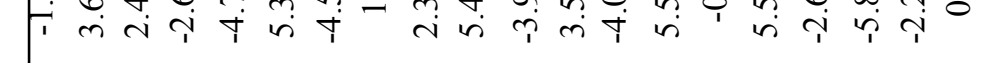

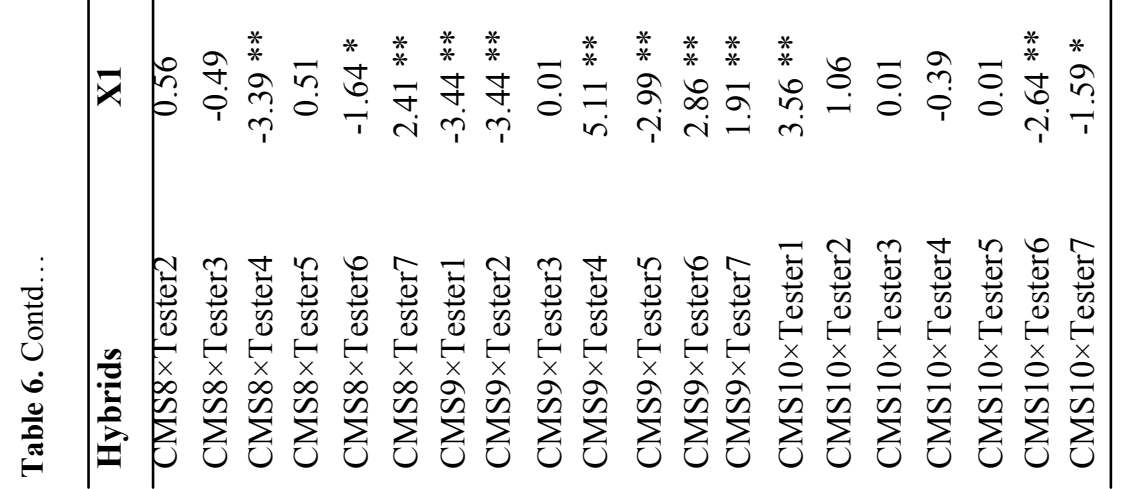

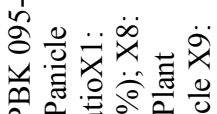

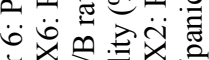
क्ष

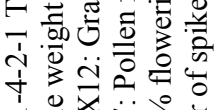

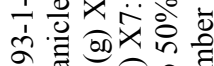
ò

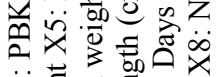

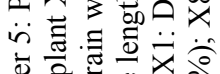
案

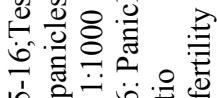

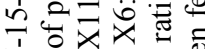

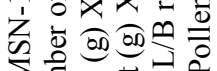

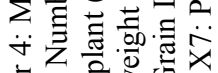

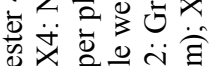
क्षे

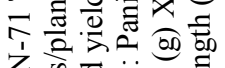

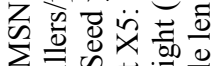

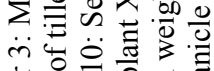

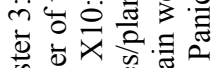

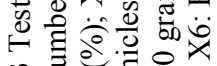
告

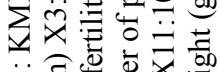

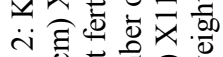

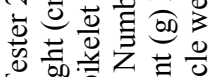

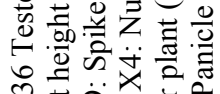

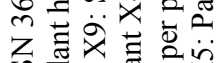

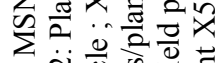

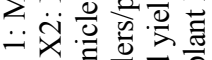
悹 bo

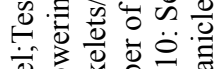

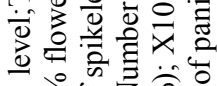
oㅇㅎㅇ iin 焉言觉焉

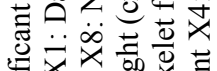

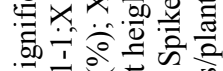

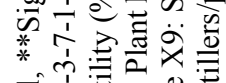

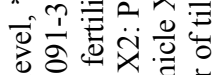
年

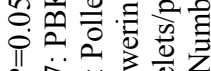

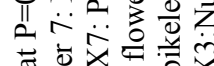

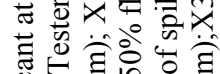

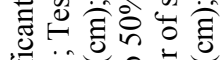

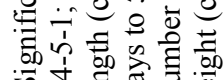




\section{REFERENCES}

Abhinav Sao and Motiramani, N. K. (2006). Combining ability analysis for yield and yield contributing traits using cytoplasmic male sterility-fertility restoration system in rice hybrids. Jordan Journal of Agricultural Sciences, 2(1):29-34.

Anand Kumar., Singh, N. K. and Chaudhory, V. K. (2004). Line $\mathrm{x}$ Tester analysis for grain yield and related characters in rice. Madras Agricultural Journal, 91(4-6): 56-59.

Arunachalam, V. (1976). Evaluation of diallel crosses by graphical and combining ability methods. Indian Journal of Genetics, 36(3):358-366

Dadilakshmi and Upendra (2014). Combining ability analysis for quality and nutritional traits in rice. International Journal of Farm Sciences, 4(2):15-23

Damodar Raju, S., Sudheer Kumar., Surender Raju. and Srijan, A., (2014). Combining ability studies in the selected parents and hybrids in rice (Oryza sativa L.). International Journal of Pure \& Applied Bioscience, 2 (4): 271-279.

Faiz, F. A., Sabar, M., Awan, T. H., Ijaz, M. and Manzoor, Z. (2006). Heterosis and combining ability analysis in basmati rice hybrids. Journal of Animal and Plant Sciences, 16(1-2): 56-59.

Ganesan, K. N., Thiyagarajan, K., Amarlal, M. K. and Rangaswamy, M. (1998). Restorers and maintainers for cytoplasmic-genic male sterile (CMS) lines of rice. Oryza, 35(2): 163-164.

Jagadeesan, S. and Ganesan, J. (2006). Combining ability studies in rice (Oryza sativa L.). Indian Journal of Agricultural Research, 40 (2): 139 - 142.

Kempthorne, O. (1957). An introduction to genetics statistics. John Wiley and Sons., New york, 458-471.
Kumar, S. T., Narasimman, R., Eswaran, R., Kumar, C. P. S. and Thangavel, P. (2008). Studies on the genetic causes of heterosis in rice (Oryza sativa L.). Advances In Plant Sciences, 21(1): 113-117.

Nadali and Babaein, J. (2010). Heterosis and combining ability analysis for yield and related traits in hybrid rice. International Journal of Biology, 2(2): 222-231

Patil, S. R., Vashi, R. D., Patil, P. P. and Shinde, D. A. (2011).Combining ability in rice (Oryza sativa L.). Plant Archives, 11(1):439-442.

Saidaiah, P., Sudheer Kumar, S. and ramesha, M. S. (2010). Combining ability studies for development of new hybrids in rice over environments. Journal of Agricultural Science, 2 (2): 225-233.

Sharma, R. K. and Mani, S. C. (2008). Analysis of gene action and combining ability for yield and its components in Rice. Oryza, 42(2): 94-97.

Swamy, M. H., Gururaja Rao, M. R. and Vidyachandra, B. (2003). Studies on combining ability in rice hybrids involving new CMS lines. Karnataka, Journal of Agricultural Science, 16(2): 228-233.

Utharasu, S. and Anandakumar, C. R. (2013). Heterosis and combining ability analysis for grain yield and its component traits in aerobic rice (Oriyza sativa L.) cultivars. Electronic Journal of Plant Breeding, 4 (4):1271-1279.

Vanaja, T., Luckins, C. Babu., Radhakrishnan, V. V. and Pushkaran, K. (2003). Combining ability analysis for yield and yield components in rice varieties of diverse origin. Journal of Tropical Agriculture, 14: 7-15.

Yuan, L. P. and Virmani, S. S. (1994). Status of hybrid rice research and development. In; Hybrid Rice, Smith, W.H., (Ed.), IRRI, Manila, Philippines, pp:7-24. 